\title{
Information Technology Governance Analysis Of Stmik Palcomtech In The New Normal Era Using Cobit 2019 Method
}

\author{
Fahmi ajismanto ${ }^{1)}$, Surahmat ${ }^{2}{ }^{*}$ \\ ${ }^{1) 2}$ STMIK Palcomtech, Indonesia \\ ${ }^{1)}$ fahmi_ajismanto@palcomtech.ac.id, ${ }^{2)}$ surahmat@palcomtech.ac.id
}

\begin{abstract}
The pandemic conditions experienced by the world today inevitably force us to practice social distance so that gatherings involving large numbers of people must be avoided first. In universities, especially in the city of Palembang, the use of information technology and learning media is mandatory due to the decision of the minister of education which requires universities to carry out online learning activities. So that information technology governance during a pandemic also has a major influence in the implementation of teaching and learning activities in universities to ensure the quality of the learning and teaching process carried out so that it must be known the shortcomings and advantages of governance which is carried out by conducting further analysis of technology governance in accordance with with the initial goal of education at the university. The method that can be used is to apply the Cobit 2019 where with this method the current maturity level can be known in the application of information technology. The research method in this study uses a descriptive-quantitative method by describing the indicators used as the basis for measurement taken by the Cobit 2019 literature. This study discusses information technology governance form of Design Factor 1 (Enterprise Strategy) to Design Factor 10 (Technology Adoption Strategy) with the result that there are 13 important processes out of 40 total processes in the Cobit 2019 domain that must be considered at STMIK Palcomtech, namely EDM03, APO08, DSS05 EDM02, APO04, APO09, APO12, APO13, BAI01, BAI02, BAI03, BAI06, MEA03.
\end{abstract}

Keywords: Cobit 2019, Governance, Information Technology

\section{INTRODUCTION}

The pandemic conditions experienced by the world today inevitably force us to practice social distance so that gatherings involving large numbers of people must be avoided first. In Indonesia itself, this pandemic has resulted in major changes, especially in the field of education where the use of information technology and learning media in education is the key to the implementation of the teaching and learning process. Information technology governance during the pandemic also has a major influence on the implementation of teaching and learning activities in universities, so it is necessary to know the advantages and disadvantages by conducting further analysis of technology governance in accordance with the initial objectives of education at the university. The method that can be used is to apply the Cobit Framework 2019 where with this method the current maturity level can be known in the application of information technology (Wardani \& Puspitasari, 2014).

While in this study, researchers conducted research on STMIK Palcomtech where this university uses new information technology in the teaching and learning process in the form of the Palcomtech Online Learning application so it is necessary to analyze the use of information technology governance (Wilkin \& Chenhall, 2020)(Guzmán \& Correa, 2018), especially its application in the new normal era. The use of the Cobit 2019 framework method itself is used because this framework provides measures, indicators, processes and a collection of best practices to help institutions optimally manage information technology and develop appropriate controls on information technology management, especially for universities (Atrinawati et al., 2021)(Gerl, Von Der Heyde, Groß, Seck, \& Watkowski, 2020). With this research, it can be a guide in terms of improvement, especially in using new types of information technology by first knowing the size of the maturity level of the application of information technology so that the teaching and learning process becomes more leverage.

\section{LITERATURE REVIEW}

Researchers reviewed business documents from STMIK Palcomtech such as vision and mission documents, learning SOP, changes in strategy in the pandemic era, then identified and formulated problems to determine research

* Corresponding author

This is an Creative Commons License This work is licensed under a Creative

Commons Attribution-NoDerivatives 4.0 International License. 


\section{Journal of Computer Networks, Architecture and High Performance Computing}

Volume 3, Number 2, July 2021

https://doi.org/10.47709/cnahpc.v3i2.1097
Submitted : Sep 19, 2021

Accepted : Nov 2, 2021

Published : Nov 11, 2021

objectives and benefits (Ishlahuddin, Handayani, Hammi, \& Azzahro, 2020). In addition, a literature study on the 2019 Cobit framework was also carried out. In this research data collection, observations and interviews were carried out (Saputra, Abdullah, Tandirau, Ramadhani, \& Atrinawati, 2020).

In the governance design, you can find an analysis of the information technology governance system that fits your needs. The researcher will design the governance system by providing the COBIT 2019 Design Tool Kit factor value (Wijaya, 2020). The design assessment is:

1. Understanding/understanding the context and company strategy, company targets, risk profile, then understanding issues related to information technology (IT) in the new normal era or the 2019 Covid pandemic (Anoruo, 2019).

2. then determine the scope of the Palcomtech STMIK governance system, taking into account the interests of the strategy, objectives, risk profile, problems in the new normal era (Irma Suryani, 2015).

3. then improve governance by considering the threat landscape, needs, compliance, IT role, sourcing model, IT implementation methodology, IT adoption, and considering the size of the company (Putra \& Rahayu, 2020).

4. Then the last stage provides conclusions on the design of the Palcomtech STMIK Governance system

Previous studies that discussed the use of the 2019 Cobit Framework include research entitled Adjusting the Governance System at the Kalimantan Institute of Technology Using Cobit 2019 in this study resulted in a governance system design from the core model of Cobit 2019 as many as 18 core models that the Kalimantan Institute of Technology must run (Maulana et al., 2020). Another study entitled Governance of Information Technology Using Cobit 2019 At PSI Muria Kudus University was carried out in 11 process domains and the domain maturity result was 3.37 then the gap analysis obtained results of 1.63 so that improvements are needed in the central governance of the Muria Kudus University information system(Wabang, Rahma, Widodo, \& ..., 2021). While in this study, researchers conducted research on STMIK Palcomtech where this university uses new information technology so it is necessary to analyze the use of information technology governance, especially its application in the new normal era (Fikri, Priastika, Octaraisya, Sadriansyah, \& Trinawati, 2020).

\section{METHOD}

The research method in this study uses a descriptive-quantitative method by describing the indicators used as the basis for measurement taken by the Cobit 2019 literature framework using measurements in the form of numbers(Sugiyono, 2017)(Jayusman \& Shavab, 2020). As for the stages of the research itself are as follows :

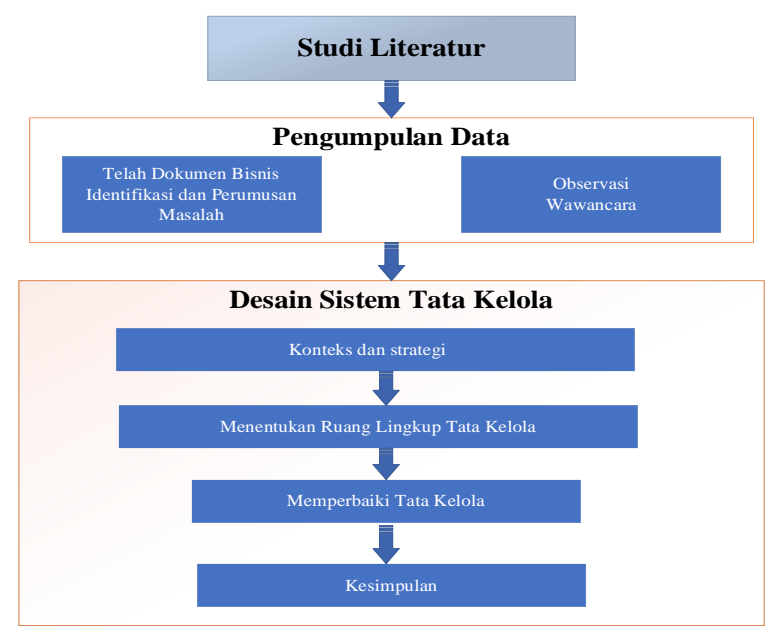

Fig. 1 Research Stages

Based on the research stages in Fig 1, it can be seen that the stages were carried out starting from the literature study stage by identifying business documents, conducting observations and interviews related to the ongoing process, after that the governance design stage was carried out based on the COBIT 2019 framework so that conclusions were obtained regarding the governance carried out at STMIK Palcomtech

* Corresponding author 


\section{RESULT}

In this study, an analysis of information technology governance was carried out with the process domains in the form of Design Factor 1 (Enterprise Strategy) to Design Factor 10 (Technology Adoption Strategy) with the result that there were 40 processes in the Cobit 2019 domain.

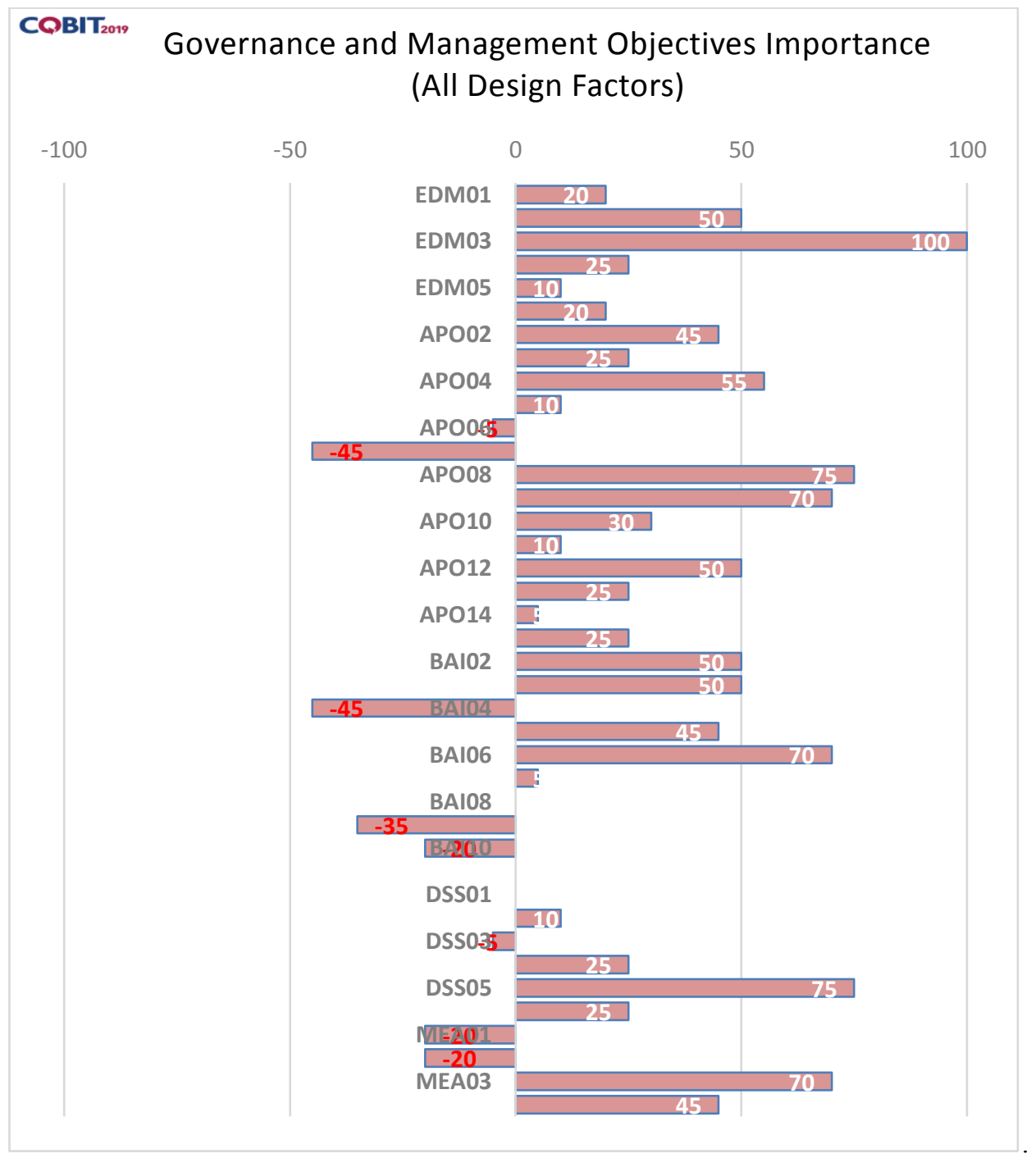

Fig. 2 Result

From the results of 40 processes carried out on information technology governance at STMIK Palcomtech, it is known that there are 3 processes that have processes with Level 4 so that improvements need to be made to these processes, besides that there are also 10 processes with level 3 which also need improvements or adjustments so that the result of better information technology governance for STMIK palcomtech. 3 processes that have level 4 are EDM03, APO08, DSS05, then 10 processes that have level 3 are EDM02, APO04, APO09, APO12, APO13, BAI01, BAI02, BAI03, BAI06, MEA03.

\section{DISCUSSIONS}

In this study, an analysis was carried out on the management of STMIK Palcomtech technology using the design factors found in Cobit 2019 starting from design factors 1 to 10 .

* Corresponding author 
Based on the results of observations/interviews, the assessment of value design factors in STMIK Palcomtech. Enterprise Strategy STMIK Palcomtech can be seen in Figure 3. Assessment of corporate strategy design factors. The highest score is on the Client Service/Stability factor with a value of 5 because palcomtech is a university that is engaged in services

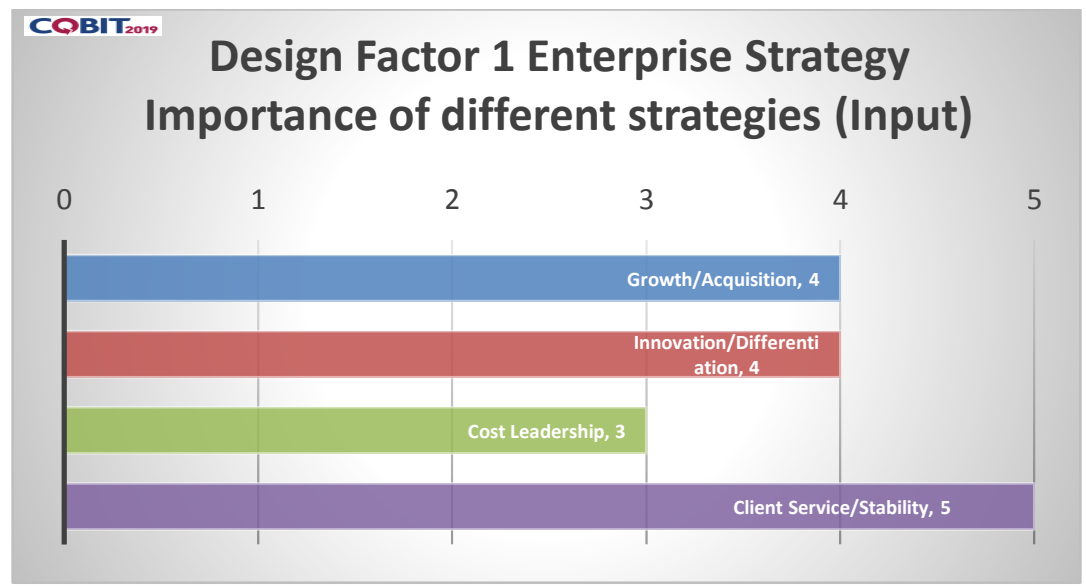

Fig. 3 Design Factor 1 Enterprise Strategy

Design Factor 2 Enterprise Goals stages get results as Figure 4 It can be seen that EG10, and EG11, are enterprise goals with the highest score of 4 .

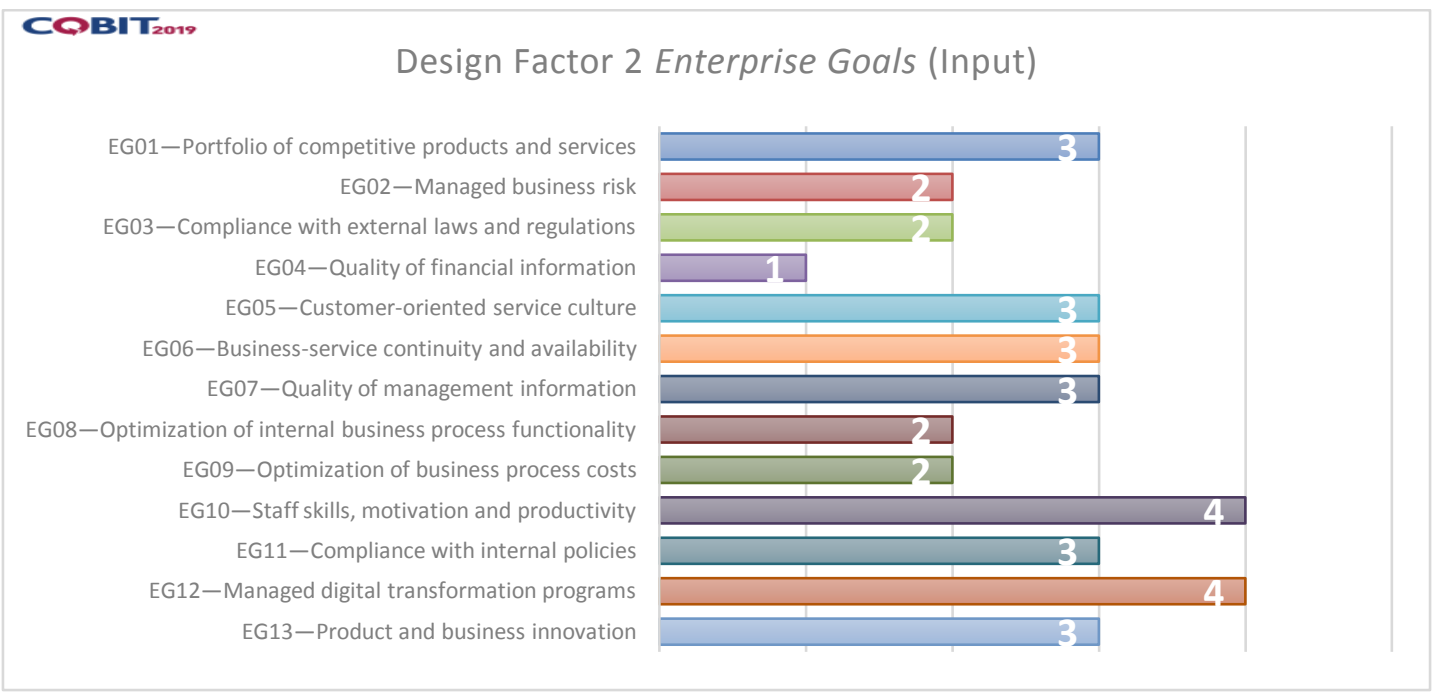

Fig. 4 Design Factor 2 Enterprise Goals

Design Factor 3 IT Risk Profile stages get results as Figure 5 In this case, the category that has a risk rating very high is data and information management with the score is 25 .

* Corresponding author 
Journal of Computer Networks, Architecture and

High Performance Computing

Submitted : Sep 19, 2021

Volume 3, Number 2, July 2021

https://doi.org/10.47709/cnahpc.v3i2.1097

Accepted : Nov 2, 2021

Published : Nov 11, 2021

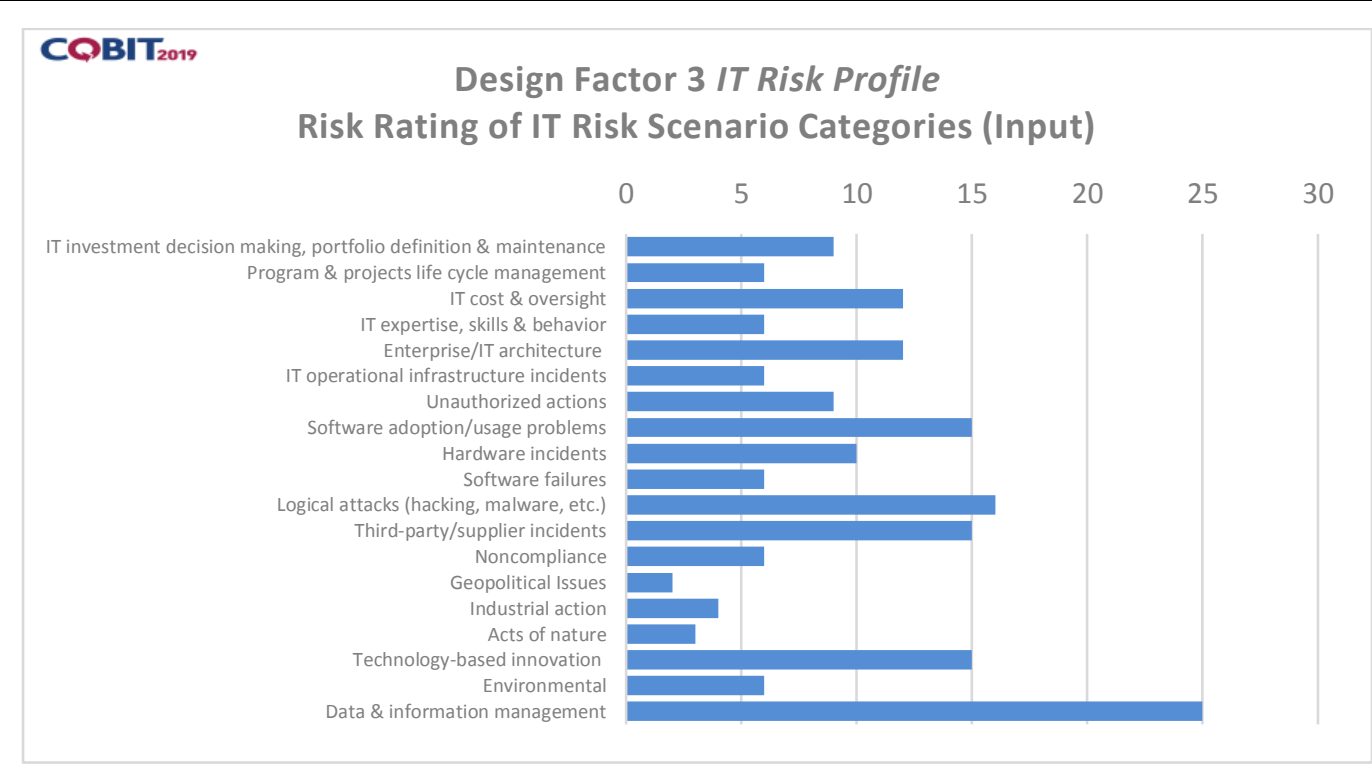

Fig. 5 Design Factor 3 IT Risk Profile

Design Factor 4 I\&T Related Issues stages get results as Figure 6

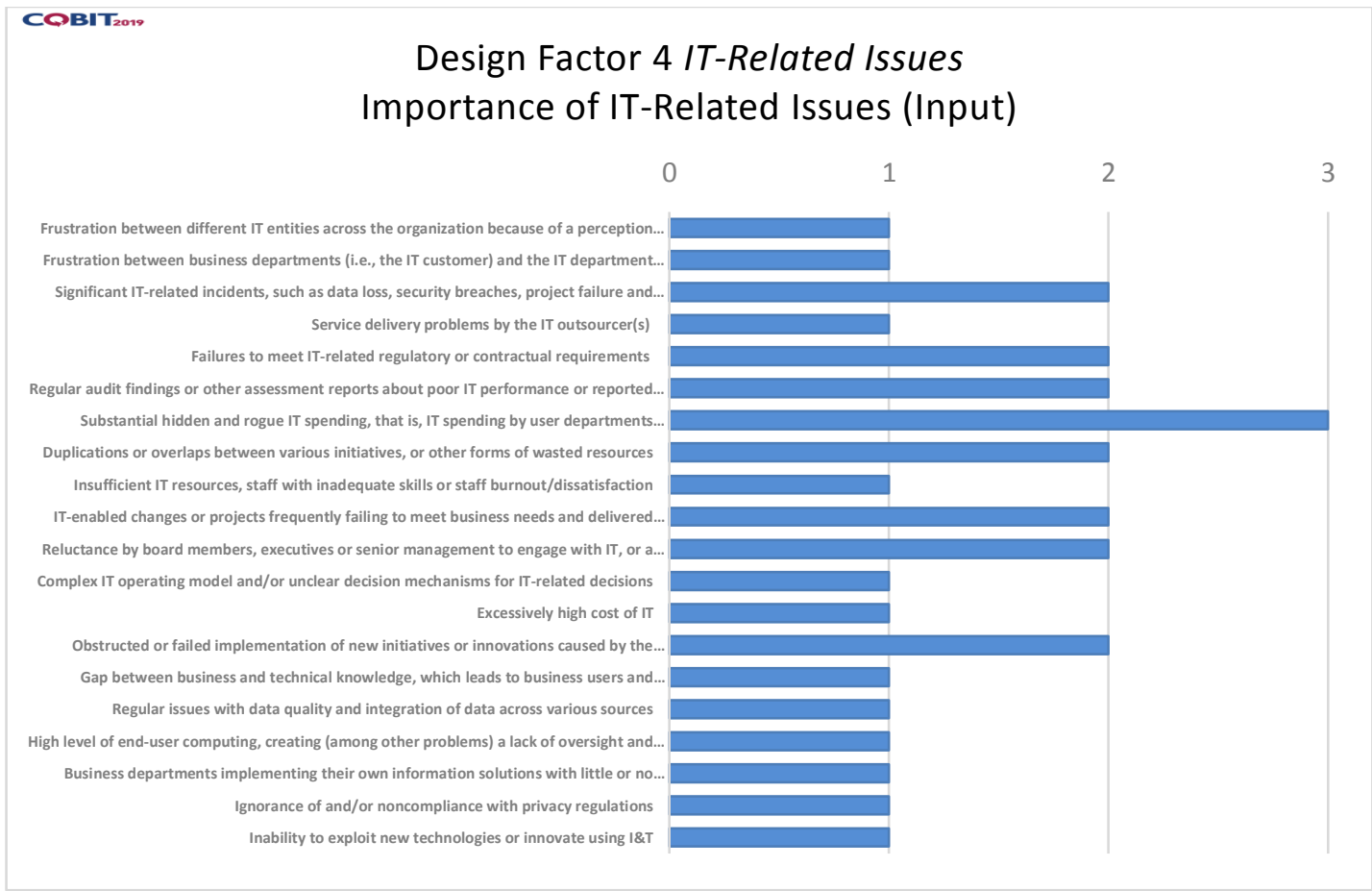

Fig 6. Design Factor 4 I\&T Related Issues

Design Factor 5 Threat Landscape Based on observations, the business environment of Palcomtech tertiary education has a normal threat level of $20 \%$ and a high value of $20 \%$. Palcomtech is one of the universities in designing business processes, regulations, and well-organized management operations proven to have experience in reporting and auditing, Palcomtech universities are also under the guidance of LLDIKTIwilyah 2 so synchronization to PDDIKTI if there is a problem will be easily detected.

* Corresponding author

This is an Creative Commons License This work is licensed under a

Creative Commons Attribution-NoDerivatives 4.0 International License. 


\section{Journal of Computer Networks, Architecture and High Performance Computing}

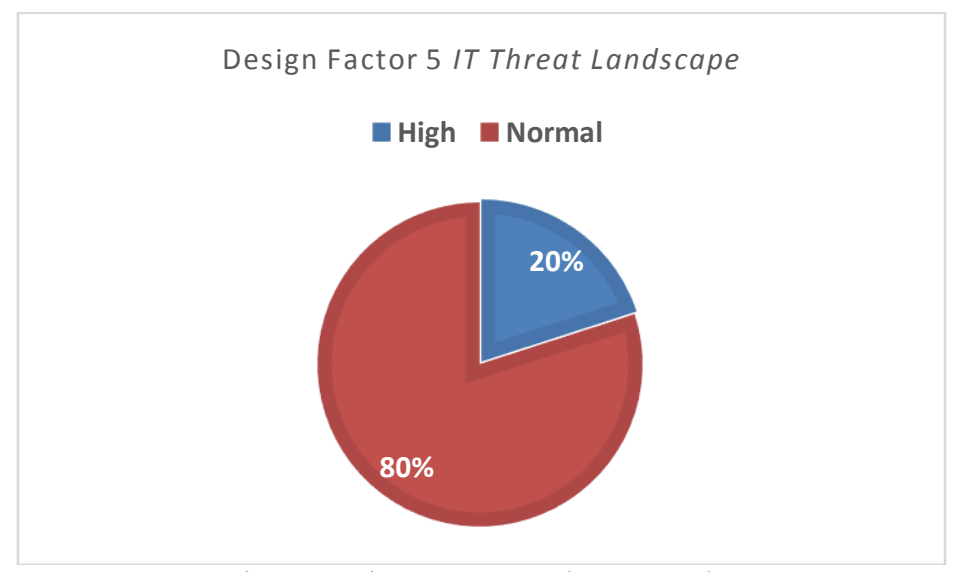

Fig 7. Design Factor 5 Threat Landscape

Design Factor 6 Compliance Requirement This design factor 6 aims to identify the linkage of compliance needs and demands to be met by Palcomtech College, identifying this need there are 3 types of compliance levels, first high where the company is subject to compliance requirements which are most often or higher related to the industrial sector or geopolitical conditions, then the second value is the Normal level of compliance where the company is subject to a set of requirements/compliances that are common in several industries. Then the level of compliance is Low where the company is subject to a series of Minimum/regular compliance requirements where the average value is lower. the three types must be rated $0 \%$ and $100 \%$ with an average value of $100 \%$. then the results of the observation Design Factor 6: Compliance Requirement research known value hight 75\%, Normal 20\%, Low 5\%.

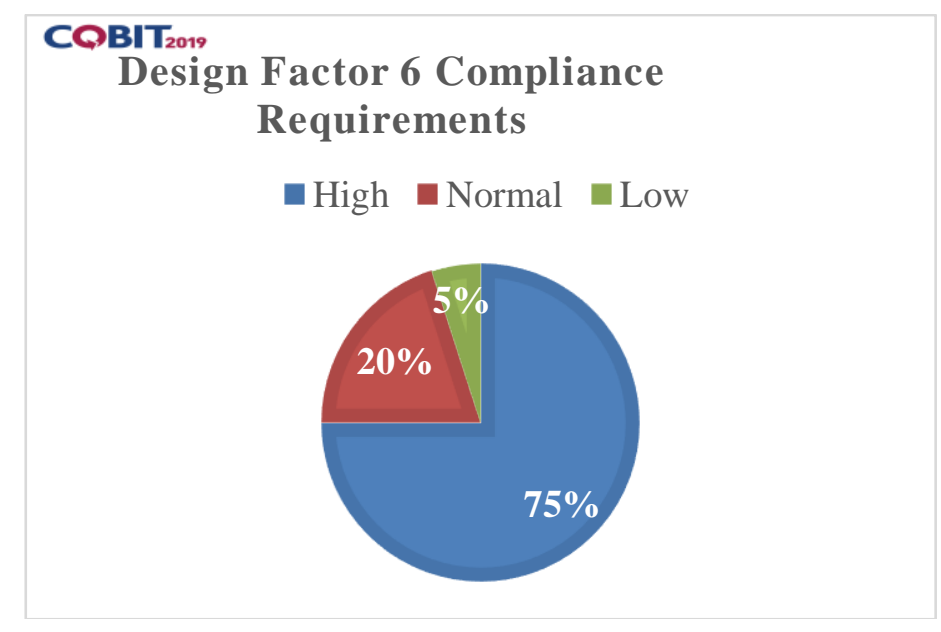

Fig 8. Design Factor 6 Compliance Requirement

Design Factor 7 Role of IT the stage of identifying the IT role of SMIK Palcomtech. Assessments related to the role of information technology for related organizations are divided into 4 types. First information technology does not play an important role in running and sustaining the Company's business processes and services/innovation, then the factory where IT fails, has a direct impact on the running/continuity of business processes and services. Then turnaround, namely IT is seen as a driver for innovation in business processes and services. Another type is strategic, namely IT is very important to run and innovate in the organization's business processes and services. With information on the importance rating given, namely, 1: not important, 2: quite important, 3: important, 4: very important, and 5: most important.

* Corresponding author 


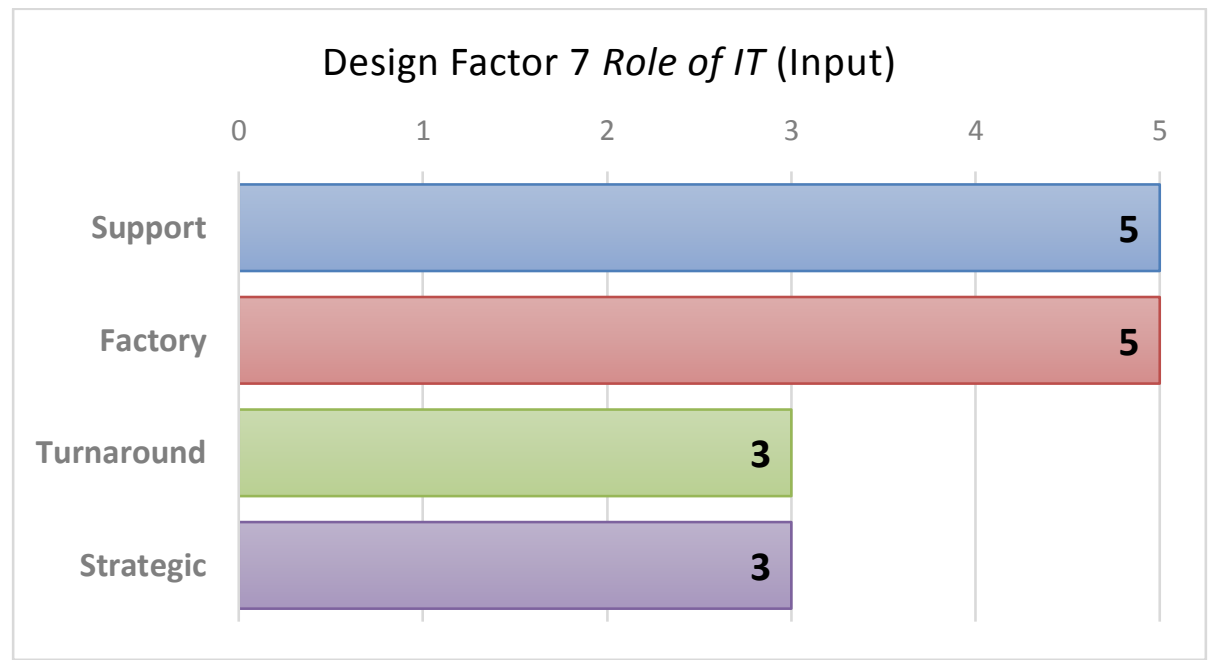

Fig 9. Design Factor 7 Role of IT

Design Factor 8 Sourcing Model of IT Identification of the IT model applied to the STMIK Palcomtech, the results obtained after interviews with IT staff related to the type of source of the IT model, where it is known that 3 categories are: outsourcing, in Palcomtech here is no IT service managed by a third party with $0 \%$ Velue, then the category 2 clouds, Palcomtech at this time Most of them have maximized the use of the cloud in providing IT services to both academic and non-academic users with a score of $65 \%$. The last category 3 is insourced, Palcomtech which has provided its own IT staff and services with a velue value of $35 \%$.

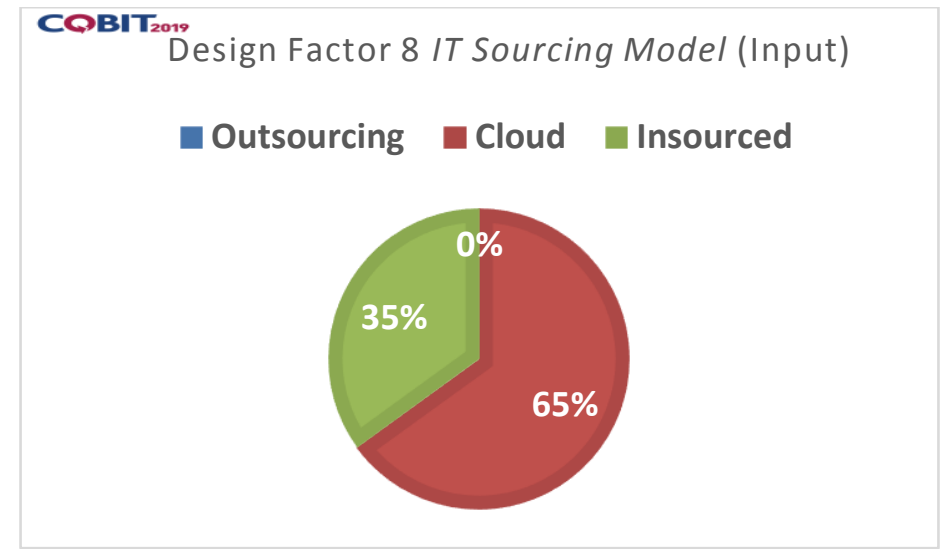

Fig 10. Design Factor 8 Sourcing Model of IT

Design Factor 9 IT Implementation Methods, Implementation at Palcomtech get score agile value $40 \%$ and traditional velue $60 \%$

* Corresponding author 


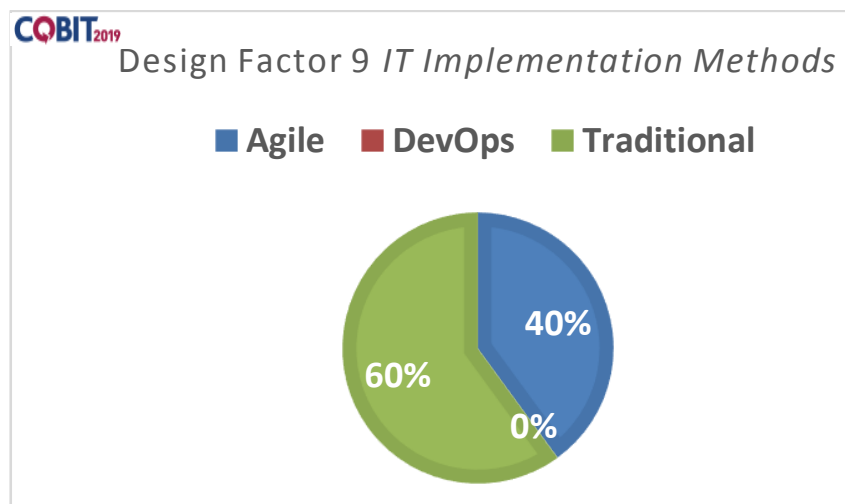

Fig 11. Design Factor 9 IT Implementation Methods

Design Factor 10 Technology Adoption Strategy At Palcotech College, it is known that $90 \%$ of the number of followers is because Palcomtech has applied technology in the company's operations, both academic and nonacademic. and $10 \%$ slow adopter rate because there are still some activities using manual systems such as the research submission service process and some teaching and learning processes

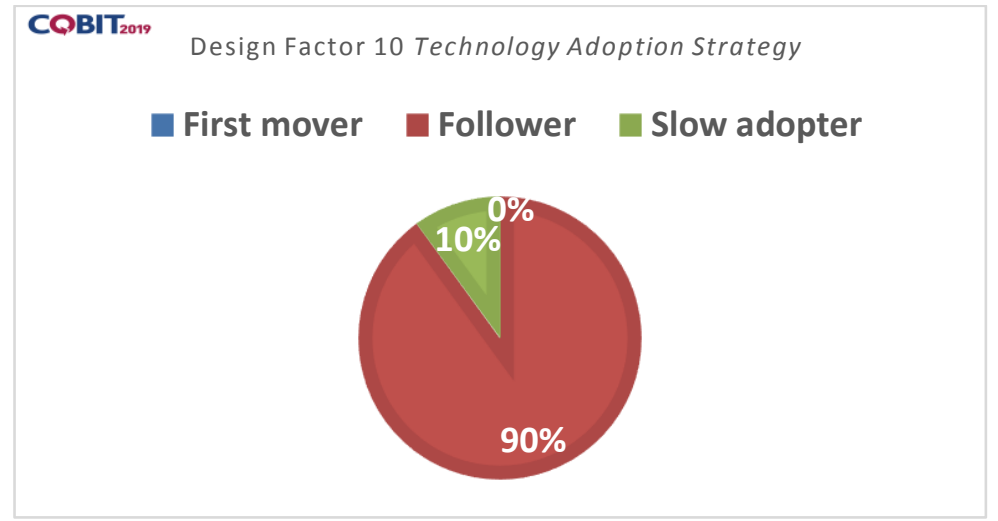

Fig 12. Design Factor 10 Technology Adoption Strategy

COBIT 2019 has provided a Design Tool Kit, the conclusion is that the entire governance design process has been assessed from each process along with the target capability so that it is known that not all important categories are identified. in table 1

Table 1

Governance/Management Goals at Level 1- Level 4

\begin{tabular}{llcc}
\hline Referensi & \multicolumn{1}{c}{ Objektif Tata Kelola/Manajemen } & Prioritas & $\begin{array}{c}\text { Target Process } \\
\text { Capability Level }\end{array}$ \\
\hline EDM01 & Ensured Governance Framework Setting and Maintenance & 20 & Level 1 \\
EDM02 & Ensured Benefits Delivery & 50 & Level 3 \\
EDM03 & Ensured Risk Optimization & 100 & Level 4 \\
EDM04 & Ensured Resource Optimization & 25 & Level 2 \\
EDM05 & Ensured Stakeholder Engagement & 10 & Level 1 \\
APO01 & Managed I\&T Management Framework & 20 & Level 1 \\
APO02 & Managed Strategy & 45 & Level 2 \\
APO03 & Managed Enterprise Architecture & 25 & Level 2 \\
APO04 & Managed Innovation & 55 & Level 3 \\
APO05 & Managed Portfolio & 10 & Level 1 \\
APO06 & Managed Budget and Costs & -5 & Level 1
\end{tabular}

* Corresponding author 


$\begin{array}{llcc}\text { APO07 } & \text { Managed Human Resources } & -45 & \text { Level 1 } \\ \text { APO08 } & \text { Managed Relationships } & 75 & \text { Level } 4 \\ \text { APO09 } & \text { Managed Service Agreements } & 70 & \text { Level 3 } \\ \text { APO10 } & \text { Managed Vendors } & 30 & \text { Level 2 } \\ \text { APO11 } & \text { Managed Quality } & 10 & \text { Level 1 } \\ \text { APO12 } & \text { Managed Risk } & 50 & \text { Level 3 } \\ \text { APO13 } & \text { Managed Security } & 25 & \text { Level 3 } \\ \text { APO14 } & \text { Managed Data } & 5 & \text { Level 1 } \\ \text { BAI01 } & \text { Managed Programs } & 25 & \text { Level 3 } \\ \text { BAI02 } & \text { Managed Requirements Definition } & 50 & \text { Level 3 } \\ \text { BAI03 } & \text { Managed Solutions Identification \& Build } & 50 & \text { Level 3 } \\ \text { BAI04 } & \text { Managed Availability and Capacity } & -45 & \text { Level 1 } \\ \text { BAI05 } & \text { Managed Organizational Change } & 45 & \text { Level 2 } \\ \text { BAI06 } & \text { Managed IT Changes } & 70 & \text { Level 3 } \\ \text { BAI07 } & \text { Managed IT Change Acceptance and Transitioning } & 5 & \text { Level 1 } \\ \text { BAI08 } & \text { Managed Knowledge } & 0 & \text { Level 1 } \\ \text { BAI09 } & \text { Managed Assets } & -35 & \text { Level 1 } \\ \text { BAI10 } & \text { Managed Configuration } & -20 & \text { Level 1 } \\ \text { BAI11 } & \text { Managed Projects } & 0 & \text { Level 1 } \\ \text { DSS01 } & \text { Managed Operations } & 0 & \text { Level 1 } \\ \text { DSS02 } & \text { Managed Service Requests and Incidents } & 10 & \text { Level 1 } \\ \text { DSS03 } & \text { Managed Problems } & -5 & \text { Level 1 } \\ \text { DSS04 } & \text { Managed Continuity } & 25 & \text { Level 2 } \\ \text { DSS05 } & \text { Managed Security Services } & 75 & \text { Level 4 } \\ \text { DSS06 } & \text { Managed Business Process Controls } & 25 & \text { Level 2 } \\ \text { MEA01 } & \text { Managed Performance and Conformance Monitoring } & -20 & \text { Level 1 } \\ \text { MEA02 } & \text { Managed System of Internal Control } & -20 & \text { Level 1 } \\ \text { MEA03 } & \text { Managed Compliance With External Requirements } & 70 & \text { Level 3 } \\ \text { MEA04 } & \text { Managed Assurance } & 45 & \text { Level 2 }\end{array}$

\section{CONCLUSION}

Based on the results of the analysis that has been carried out, it can be concluded that:

1. The analysis was carried out on design factor 1 to design factor 10 using COBIT 2019 as the basis for assessing information technology governance at STMIK Palcomtech

2. Processes that have level 4 process results are EDM03, APO08, DSS05 so that governance adjustments need to be made so that there are improvements in the system carried out. While the processes that have level 3 process results are EDM02, APO04, APO09, APO12, APO13, BAI01, BAI02, BAI03, BAI06, MEA03 which are also included in the important category for improvement. With a total of 13 important processes out of 40 total processes in the 2019 cobit domain that must be considered at STMIK Palcomtech.

3. To get the results as a comparison can using other methods such as ITIL 4 or ISO 27001 which can be used as another method for improving the information technology system contained in STMIK Palcomtech..

\section{REFERENCES}

Anoruo, C. C. (2019). Employing COBIT 2019 for Enterprise Governance Strategy. ISACA Newsletter.

Atrinawati, L. H., Ramadhani, E., Fiqar, T. P., Wiranti, Y. T., Abdullah, A. I. N. F., Saputra, H. M. J., \& Tandirau, D. B. (2021). Assessment of Process Capability Level in University XYZ Based on COBIT 2019. Journal of Physics: Conference Series. https://doi.org/10.1088/1742-6596/1803/1/012033

Fikri, A. M., Priastika, H. S., Octaraisya, N., Sadriansyah, S., \& Trinawati, L. H. (2020). Rancangan Tata Kelola Teknologi Informasi Menggunakan Framework COBIT 2019 (Studi Kasus: PT XYZ). Information Management For Educators And Professionals: Journal of Information Management. https://doi.org/10.51211/imbi.v5i1.1410

Gerl, A., Von Der Heyde, M., Groß, R., Seck, R., \& Watkowski, L. (2020). Applying COBIT 2019 to IT Governance in Higher Education Establishing IT governance for the collaboration of all universities and universities of applied sciences in Bavaria. INFORMATIK 2020.

Guzmán, D. C., \& Correa, G. B. (2018). Model for information technology governance (GTI) in a university

* Corresponding author 


\section{Journal of Computer Networks, Architecture and High Performance Computing}

Volume 3, Number 2, July 2021

https://doi.org/10.47709/cnahpc.v3i2.1097
Submitted : Sep 19, 2021

Accepted : Nov 2, 2021

Published : Nov 11, 2021

environment. Computacion y Sistemas. https://doi.org/10.13053/CyS-22-4-2797

Irma Suryani. (2015). Good University Governace. Jurnal Riset Akuntansi - Volume VII / No. 2 / Oktober 2015.

Ishlahuddin, A., Handayani, P. W., Hammi, K., \& Azzahro, F. (2020). Analysing IT Governance Maturity Level using COBIT 2019 Framework: A Case Study of Small Size Higher Education Institute (XYZ-edu). 2020 3rd International Conference on Computer and Informatics Engineering, IC2IE 2020. https://doi.org/10.1109/IC2IE50715.2020.9274599

Jayusman, I., \& Shavab, O. A. K. (2020). Studi Deskriptif Kuantitatif Tentang Aktivitas Belajar Mahasiswa Dengan Menggunakan Media Pembelajaran Edmodo Dalam Pembelajaran Sejarah. Jurnal Artefak.

Maulana, H., Saputra, J., Ika, A., Fauziati, N., Berkat, D., Ramadhani, E., ... Kalimantan, I. T. (2020). Penyesuaian Sistem Tata Kelola Pada Institut Teknologi Kalimantan Dengan Menggunakan Cobit 2019 Pelayanan Teknis ( UPT ) dan tim ad hoc. Salah satu tugas pengelola TI di perguruan tata kelola teknologi informasi adalah Control Objective for Information a. Jurnal Sistem Informasi, 12(2), 2060-2074.

Putra, D. G., \& Rahayu, R. (2020). Peranan Implementasi Tata Kelola Teknologi Informasi (IT Governance) sebagai Faktor Penting dalam Meningkatkan Kinerja Perusahaan. Jurnal Inovasi Pendidikan Ekonomi (JIPE). https://doi.org/10.24036/011077110

Saputra, H. M. J., Abdullah, A. I. N. F., Tandirau, D. B., Ramadhani, E., \& Atrinawati, L. H. (2020). Penyesuaian Sistem Tata Kelola Pada Institut Teknologi Kalimantan Dengan Menggunakan Cobit 2019. JSI: Jurnal Sistem Informasi (E-Journal). https://doi.org/10.36706/jsi.v12i2.11582

Sugiyono. (2017). Metode Penelitian Bisnis (Pendekatan Kuantitatif, Kualitatif, Kombinasi dan R\&D). In Metodelogi Penelitian.

Wabang, K., Rahma, Y., Widodo, A. P., \& ... (2021). Tata Kelola Teknologi Informasi Menggunakan Cobit 2019 Pada Psi Universitas Muria Kudus. ... (Jurnal Teknologi Dan ..., VII(3), 275-282. Retrieved from https://jurnal.stmikroyal.ac.id/index.php/jurteksi/article/view/1103

Wardani, S., \& Puspitasari, M. (2014). Audit Tata Kelola Teknologi Informasi Mengunakan Framework Cobit Dengan Model Maturity Level ( Studi Kasus Fakultas AC ). Jurnal Teknologi.

Wijaya, A. (2020). Perencanaan Audit Tata Kelola Teknologi Informasi Laboratorium Kalibrasi Menggunakan Cobit 2019 (Studi Kasus: Laboratorium Kalibrasi BSML Regional II). Jurnal Fasilkom.

Wilkin, C. L., \& Chenhall, R. H. (2020). Information technology governance: reflections on the past and future directions. Journal of Information Systems. https://doi.org/10.2308/isys-52632

* Corresponding author 